\title{
676.921 .5
}

\section{「デング熱」二關スル研呪 \\ （第 2 編）}

本症二特記 $ス$ 可キ一過性「ブラスマ細胞過多症」ニ就テ

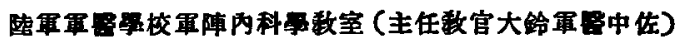

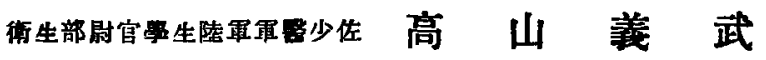

\section{第1章棈 䡒}

「プラスマ湅胞」トヘ, 2535 年 Waldeyer ガ初

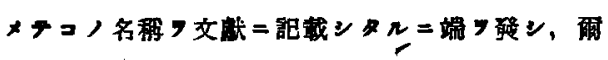

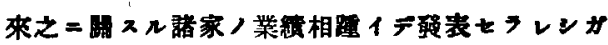

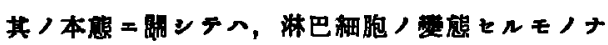
リトノ說有カナリンモ, Naegeli へ 2 元說

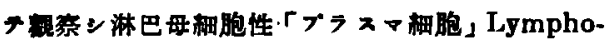
blastiache Plasmazellen 淋巴細胞性「プシスマ

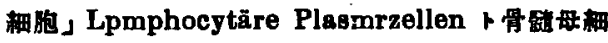
胞 Myeloblasten $コ$ 甲由來スル「ブラスマ細胞」

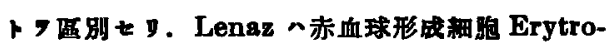
blasten $\Xi$ 由來スルトブラスマ細胞」アルフ道加

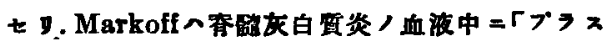
จ䚀胞性」單校細胞Plasmozelluläre Monocyten

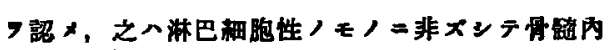

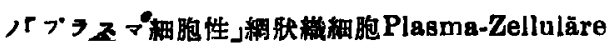

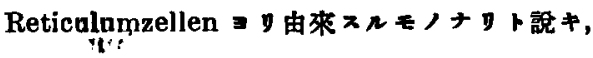

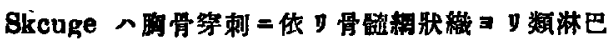
細胞 Lympooide「ブフスマ細胞」及ビ呤細胞が生

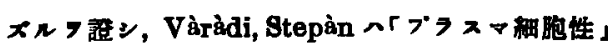

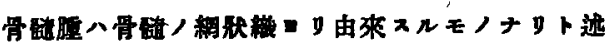

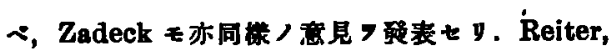
Freemann ヘ「ブラスマ㽞胞性」白血病ノ鯆

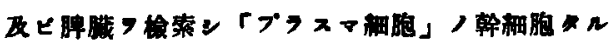
Plasma-blagten 7 裙 $x$ yト云フ。

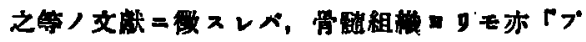

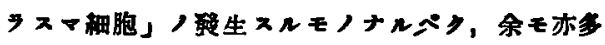

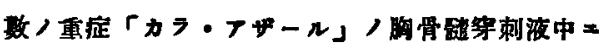

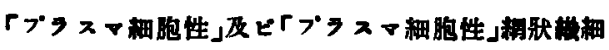

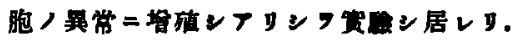

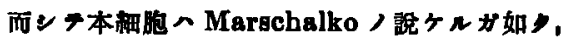

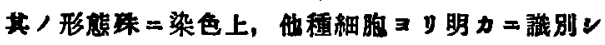

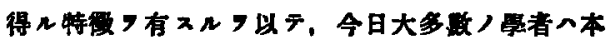

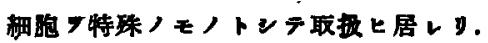

而ンテ「プシスマ細胞」が末梢血液中 =出现 ス

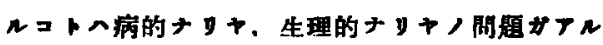
モ, 生理的血液中 $=n$, Schilling $=\Xi レ ヘ 0.5 \%$,

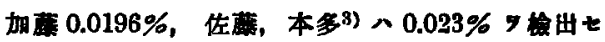

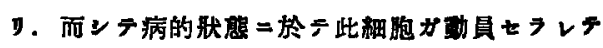

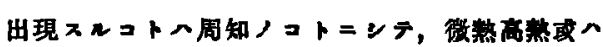

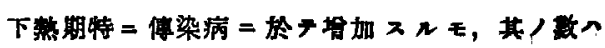

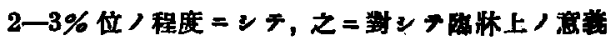

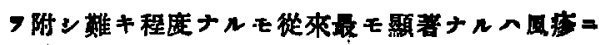

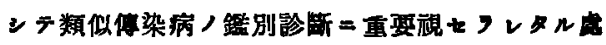
$+\boldsymbol{y}$.

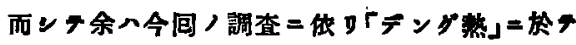

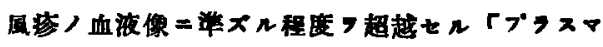
細胸過多症」八存在 スル事穴 エノ血球ノ消最二就キ論逊をントメ。 


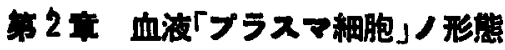
媇二分類二就テ

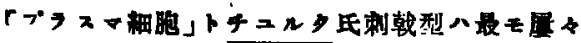

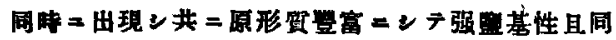

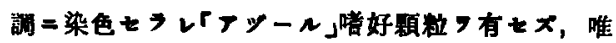

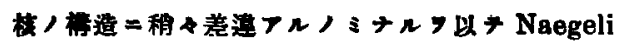
モ刺辣型フ「プラス、細胞」ノ一相ト見做ン居レ

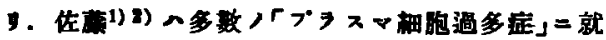

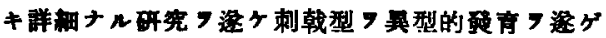

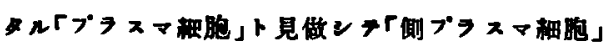
Paraplasmazelien ト㭔ビ，更二之等ノ細胞卜

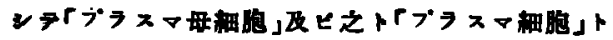

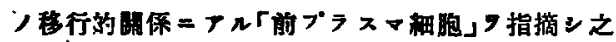

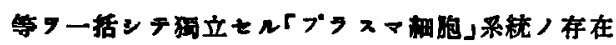
フカ說七り。

余ヘ「デング等」於テ極メテ高度ナル「ブラス

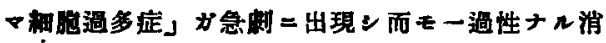

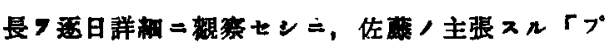

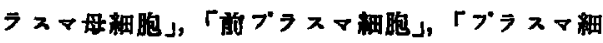

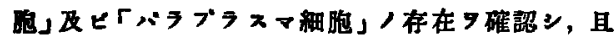

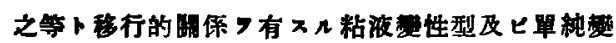

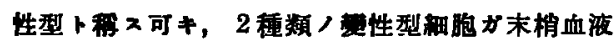

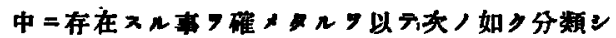

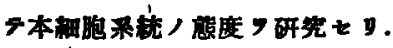

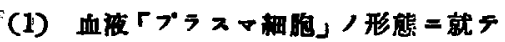

本細胞へキームザ染色法二估りテ最モ良好二

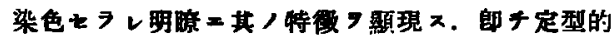

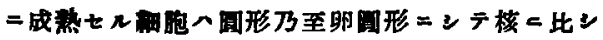
原形算特二舅富 ニンテ，且既 $=$ Unna, Marechalko

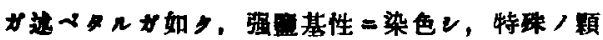
粠ナク，模ノ周国或八胞售中心部二向へ几核㑡，

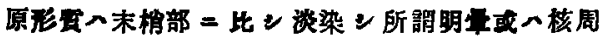

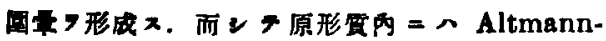
Schridde 氏顆粒 有スルコトの周知ノ亳ナルガ，

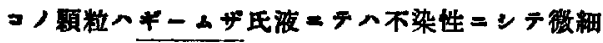

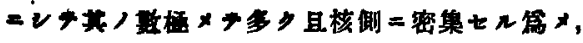

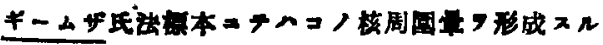

ナy.

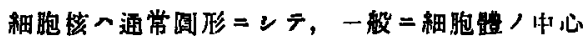

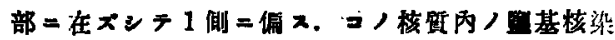

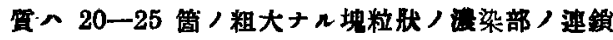

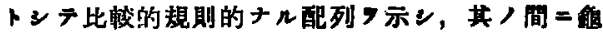
裂狀狄少ナル不染部即千正色核染留の有ン一見目

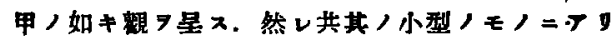

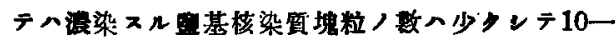
15简，時トンテの7ー8䇫ノ事厂り。核周国量人

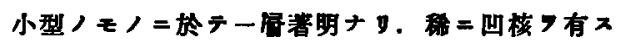

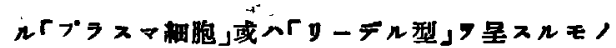

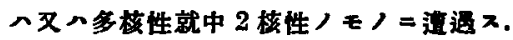

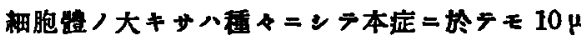
程度ノ小型ノ

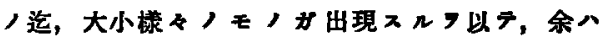
「オクーラール・ミクロメーター」ク用ヒテ下，磦

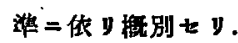

大型 $20-24 \mu$, 中型 $16-18 \mu$, 小型 $10-13 \mu$.

（2）「ブランマ細胞」/形熊 $=$ 就

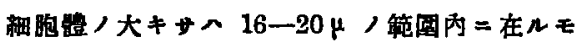

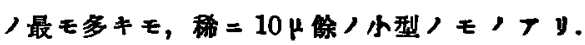

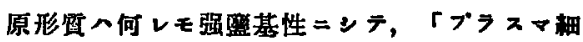

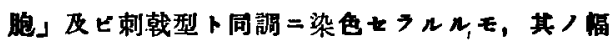

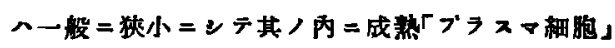

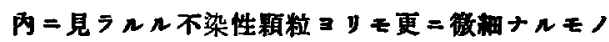

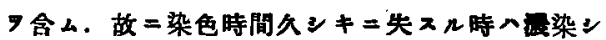

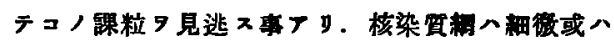

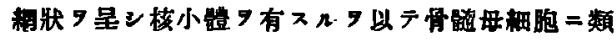

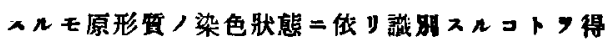

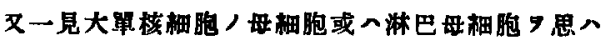

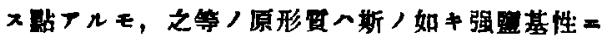

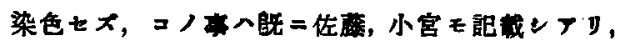

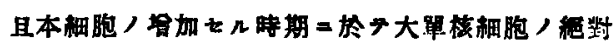

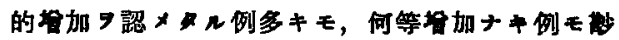
カラズ. 而モ必ズ刺戟型，「ブラスマ細胞」等ノ高

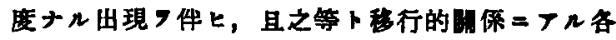

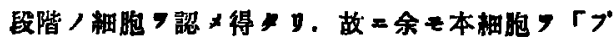




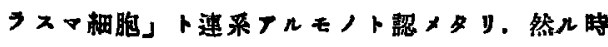
へ本湅胞ハ「プタス、維胞」ノ最初若型卜見做ズフ

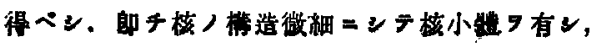

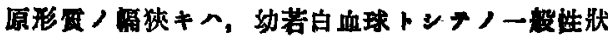
フ具借スルフ以ーナり.

(3)「前プラスマ細胞』ノ形態=就

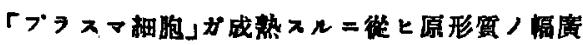

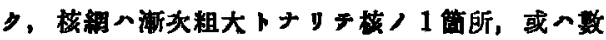

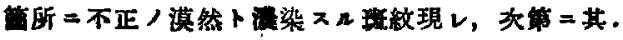
ノ程度ノ進

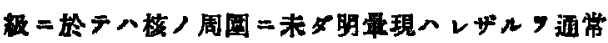

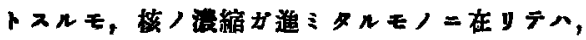

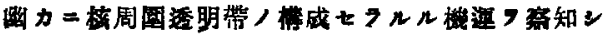
得几モノフ

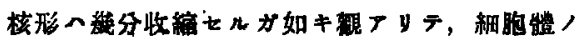
太サ八中型最モ多ク小型之二亞ギ大型八少ン.

（4）本拄／刺戟型／形態 $=$ 就テ

此細胞ハ「ブラスマ細胞」及ビ「前フラスマ細

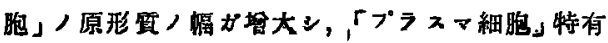

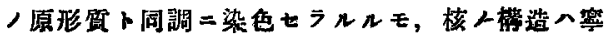

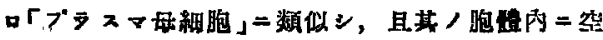

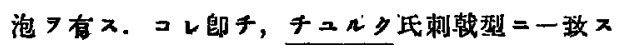

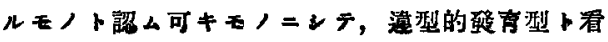
做ン得れモノンリ。

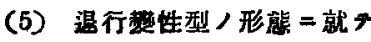

(1) 單純政性型

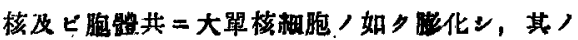

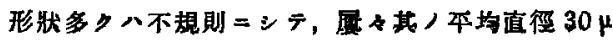

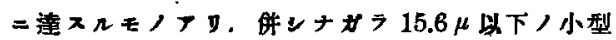

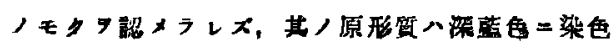

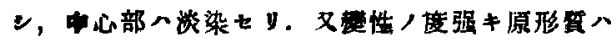
不規則ナル笑起狀又八崩㜔狀 7 是ン，且染色性モ

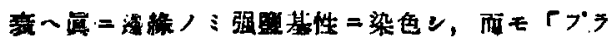
スマ細胞」二特有ナ几不染性顆粒、念么.

核八正圆ノモノ殆ドタ，不正榙国及人「》一

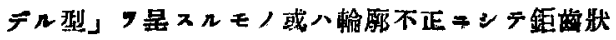

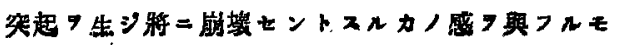

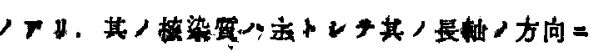

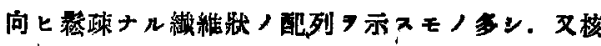

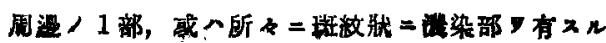

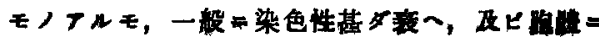
架敏形成 7 慁

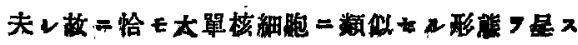

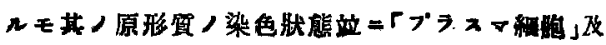

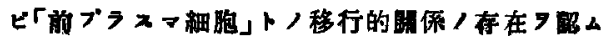

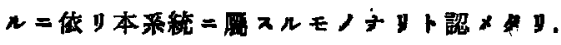

(口) 粘液程性型

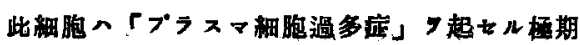

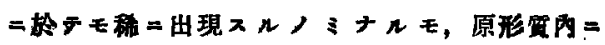

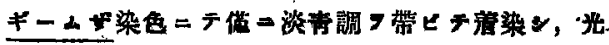

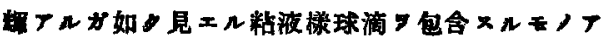
y.

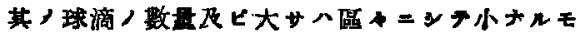

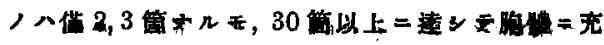

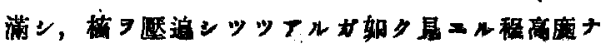

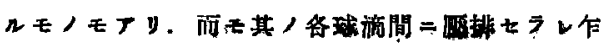

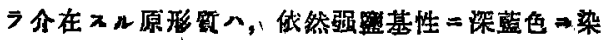

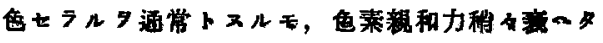

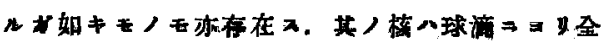

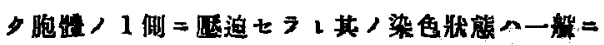

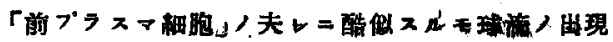
高度ナルモノニ在リテハ縮セルが㠰染急入。

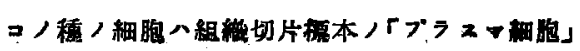
才 Russell 氏小能 7 合A像二類似七y。

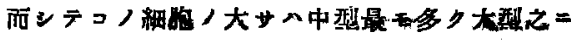

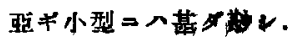

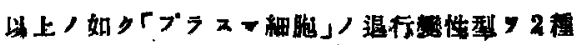

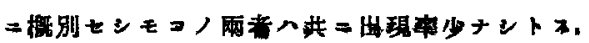
一般

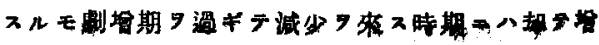

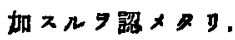

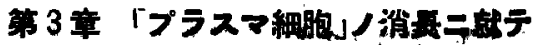

(1).「ブァスマ細胸過多还」二就フ 
今可ノ調查ニ於ヶル「プフスマ細胞」ノ消長へ首

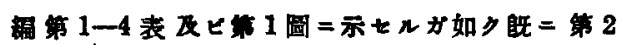
病日ヨり药現をン例てリンモ最モ著明ナル八第 7,8 病日 =シテ第 7 病日平均 $19.9 \%$, 第 8 病日平均 $19.7 \%=シ ナ$ 最高へ $38.25 \%$ 示セり。

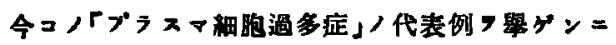
大八如 $\nu$.

\section{应例 松O定O 34 胔男 OOOOO工年}

昭和 17 年9月8日夕,惡寒 9 伴七テ解謷面痛甚

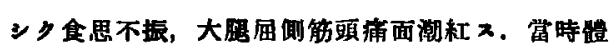

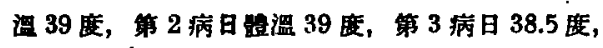
第4病日朝 37.5 度二下隆七ルモ；多再 38.3 度

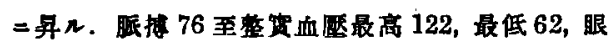

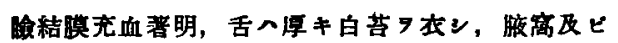

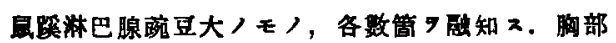

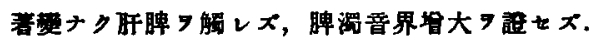

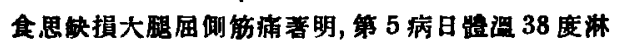

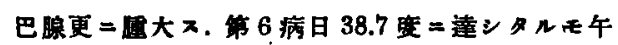

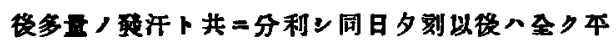

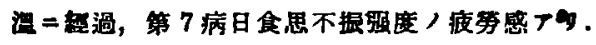

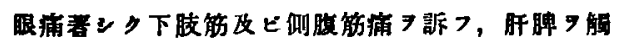

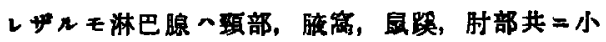

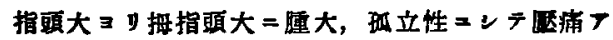

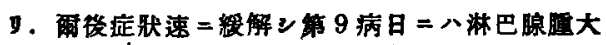
へ殆 $\mathrm{F}^{*}$ 消失ン，眼痛，結膜炎，筇消等全ク消失七

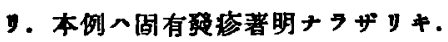

血液所見. 第 4 病日及ヒ第 7 病日，血液所見 7

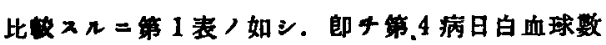
2325 ナリンモ，3日广侵 $=八 5100=$ 增加七y. 然几ニシ/䟢中性嗜好白血球八却テ減少ン, 850，

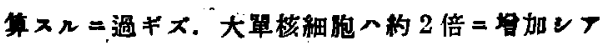

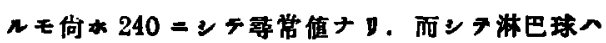
2.5 倍=合加ン1980 ワ算セ》。「ブラスマ細胞」へ

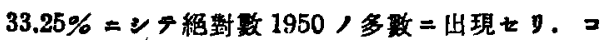
ノ柰最モ多數出現せシハ小型「ブスマ細胞」ンシ

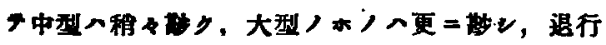

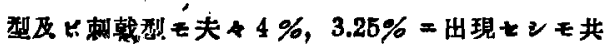

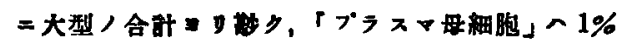

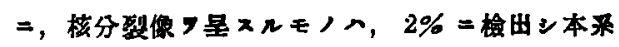
統ノ細胞が末梢血液中＝於于旺盛ナル增殖 7 管 $ア ル フ$ 知レ゙.

第 1 表「ブラスマ細胞過多症」

(代表例) 松O定O (。 34 歳)

\begin{tabular}{|c|c|c|c|c|}
\hline 䨌 & 第田 & 病 日 & 第 & 青 \\
\hline 輻 & 百分比 & 窝数 & 宿分比 & 数 \\
\hline 白血永紋数 & 2, & 25 & 5,1 & 00 \\
\hline 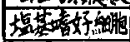 & 0,5 & 11,63 & & \\
\hline 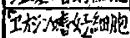 & 0,5 & 11,63 & 1,0 & 5,0 \\
\hline 中性栺好細胞 & 61,75 & 1435.7 & 16,75 & 854,3 \\
\hline 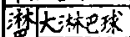 & 5,75 & 133,7 & 13,5 & 688,5 \\
\hline 理㳜已现 & 28,25 & 657,4 & 25,25 & $128 \% 8$ \\
\hline 大童核紸胞 & 5,25 & 122,1 & 4,75 & 242,3 \\
\hline 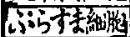 & 0,5 & 11,63 & 38,25 & 1950,8 \\
\hline 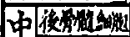 & 7,0 & 233 & 0,25 & 12,8 \\
\hline 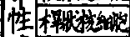 & 33,25 & 773.1 & 7.0 & $35 \% .0$ \\
\hline 2 型 & 24,25 & 563,8 & 8,25 & $42 Q 8$ \\
\hline 好 3 型 & 3,25 & 75,6 & 1,25 & 638 \\
\hline 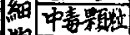 & H & & + & \\
\hline 肥校推移 & 1,482 & & 1,627 & \\
\hline 校依像 & & & 2,0 & 1020 \\
\hline 母大型 & & & 0,25 & 1275 \\
\hline 綝中型 & & & 0.5 & 25,50 \\
\hline 脂型 & & & 0,25 & 12,75 \\
\hline 觕大型 & & & 1,5 & 76,5 \\
\hline ま和型 & 0,25 & 5.8 & 3,0 & 753,0 \\
\hline 䄄胞小型 & & & 275 & 140,8 \\
\hline 成入型 & & & 275 & 140,3 \\
\hline 促建 & $0,25$. & 5,8 & 8,75 & 446,3 \\
\hline 系幣小型 & & & 12,0 & 612,0 \\
\hline 維逼大型 & & & 0.75 & 38,3 \\
\hline 行中犁 & & & 3,0 & 153,0 \\
\hline 型小梨 & & & 0,25 & 12.75 \\
\hline 可垡㻎 & & & 325 & 165,75 \\
\hline
\end{tabular}

（2）「プタスマ細巵」ノ出現带二就

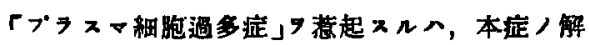

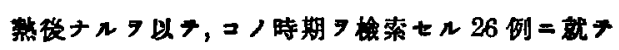

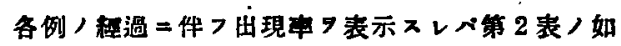

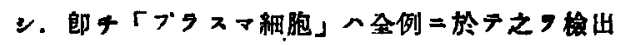

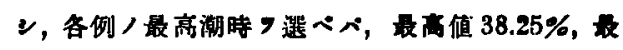
低值 3.5\% ニンテ，其ノ平均へ $16.6 \%$ トナy，26 例中 18 例二於テへ $10 \%$ 以上 
第 2 表「プラスマ細胞」フ消長 (100分比示 $x)$

\begin{tabular}{|c|c|c|c|c|c|c|c|c|}
\hline 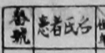 & titio & V & $\nabla$ & $\mathrm{Vl}$ & VII & VIIII & D & X \\
\hline$y_{1.0000}$ & $3 \pi^{2}$ & 1.0 & 25 & 4.75 & 18.75 & 20.75 & 4.25 & \\
\hline 22 上使 & $40^{8}$ & 1.0 & 35 & 8.0 & 220 & 190 & 11.5 & \\
\hline $21+0020$ & 319 & & & 25 & 180 & 280 & 125 & \\
\hline 20;010 & $41^{t}$ & & & 25 & 165 & 18.5 & 105 & \\
\hline 14 s00㐘。 & $88 \hat{8}$ & 0.5 & 15 & 100 & 21.0 & 13.5 & & \\
\hline $8110 \%$ & 31.5 & (25 & 10 & 5.5 & 21.5 & 356 & 165. & 20 \\
\hline 18 tho & 328 & & 1.0 & 35 & 21.0 & 270 & 140 & 10 \\
\hline 10000 & 318 & 10 & 1.5 & 85 & 245 & 155 & 80 & 05 \\
\hline $20+100$ & $26 \hat{5}$ & 05 & 1.0 & 7.5 & 265 & 165 & 25 & 10 \\
\hline \begin{tabular}{|l|l|}
260 定0 \\
\end{tabular} & $34 \hat{b}$ & 0.5 & & & 3825 & & & \\
\hline 39 t20 10 & $38 ?$ & & & & 240 & & & \\
\hline 27 乐010 & $36 \%$ & & 25 & & & & 180 & \\
\hline 25 虐口象o & $50^{5}$ & & 20 & & 120 & & & 10 \\
\hline $23: 190.00$ & $37^{\hat{b}}$ & 0.5 & & & 180 & & 25 & \\
\hline 29 + & $299^{\circ}$ & & & & & 14:0 & & \\
\hline 56 Wor & $18^{2}$ & & & & & & & 110 \\
\hline 18 1100 & $10^{\circ}$ & 20 & 5.5 & 150 & & & & \\
\hline 17 A० 장ㅇ & $12 \hat{0}$ & 1.5 & 4.0 & 110 & & & & \\
\hline 6 - 由portio & $10^{\circ}$ & as & 1.75 & 5.75 & 85 & & & \\
\hline $4^{* 0}$ ० 繁 & $10^{8}$ & Q5 & 20 & 7.5 & & & & \\
\hline $3 * 0 \neq 0$ & 15 ค & 0 & 0 & 10 & 70 & & & \\
\hline $15>00-0$ & $18 \hat{0}$ & Q.5 & 1.5 & 50 & & & & \\
\hline 16 窄०:0 & $12^{7}$ & 0 & 05 & 10 & 4.0 & & & \\
\hline 9 平过 & 278 & & 10 & 35 & & & & \\
\hline $30 / 0^{\circ} \times \mathrm{y}^{\circ}$ & $11^{7}$ & & & 25 & - & & & 4.0 \\
\hline 31 : & $88^{3}$ & & & & & 7.5 & & \\
\hline 平 坮 & & 0.75 & 192 & 5.75 & 18,90 & 19.70 & 1095 & 2.75 \\
\hline
\end{tabular}

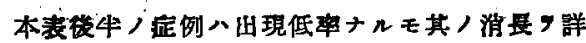

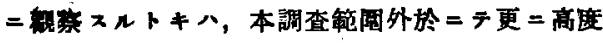

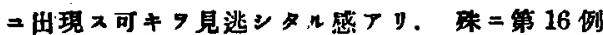
ノ如キへ第 7 病日 7 檢ンフルニ拘ラス，何水 $4 \%$ =過ギザれモ，第 1 編第 5 表 =就テ其ノ白血球

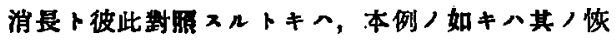

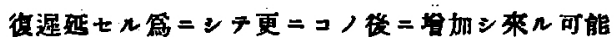
性 フ跑想スルニ難かラザルベシ

（3）「プラスマ細胞」型ノ消長二就テ （1）「ファスマ細胞」禾卜白血球總數ノ消長ノ

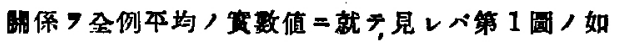
ン. 即千第 5 筷日迄八白血球減少期二八甚 出現スルノミナルモ第 6 病曰 $\mathbf{3} \boldsymbol{y}$ 白血球總数卜共

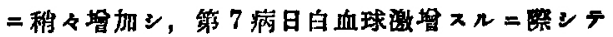

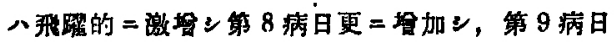

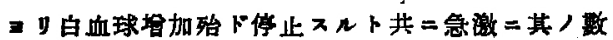

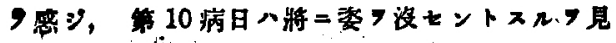

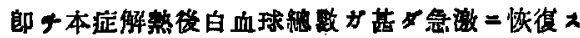
ルハ此一過性「プシスマ細胞過多症」が甚方重要ナ ル役割の演ジルナリ。

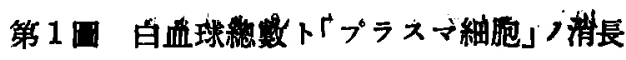

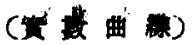

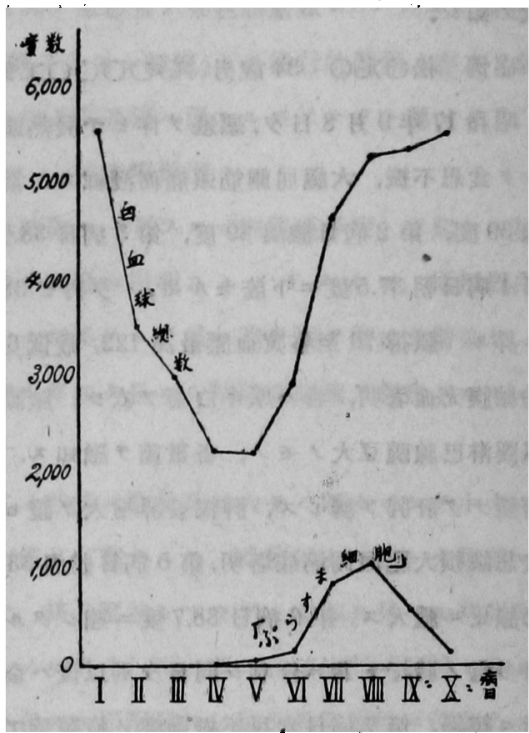

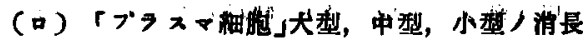

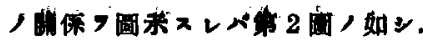

第2国「ブラスマ粗胞」大型，中型， 小型ノ消艮

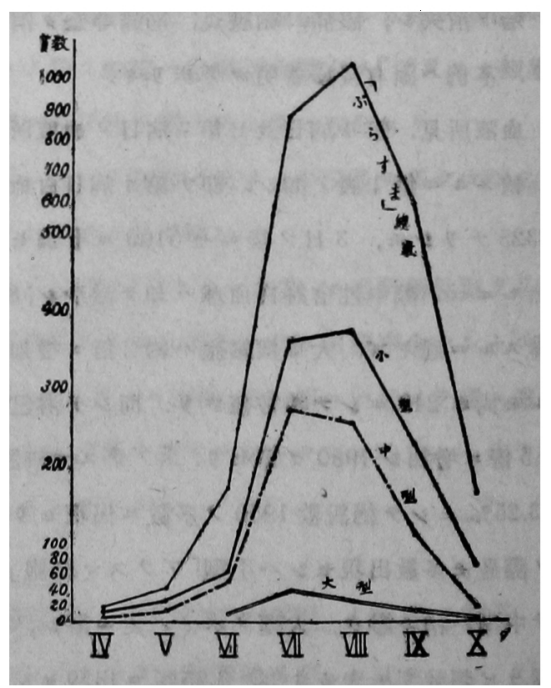




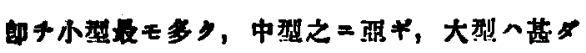
to.

之等ノ小型及ビ中型へ共

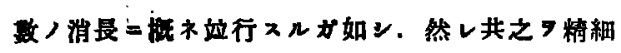

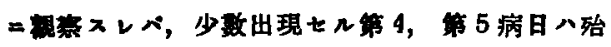

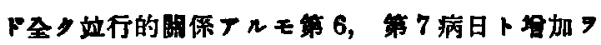

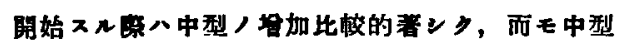
「前プラスマ細胞」ノ垥加耚明ナり(第 1 編第 1 表

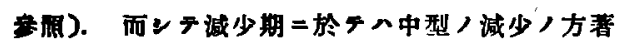
男ナり。

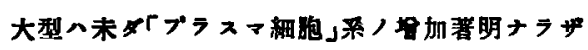

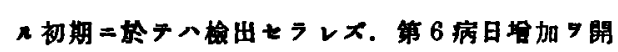

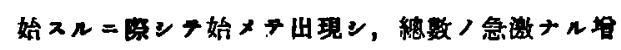

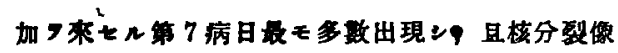
フ星スルをノ，稀 $=2$ 核性ノモノニも造遍ス几モ 減少期に祭ンテへ斯ノ如キモノフ檢出をザりキ. 斯わ几消長》他種血球ノ態度卜比隺ス几ラ病的中

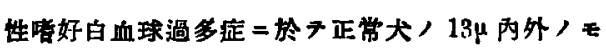

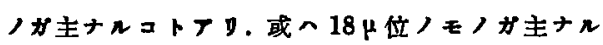

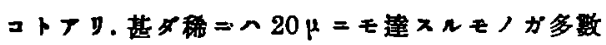

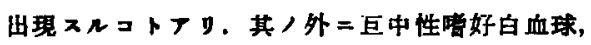

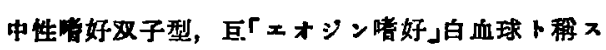

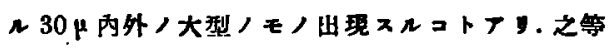
八何レも造血䑏器，新生反雄が，概ンテ旺盛ナル 軥合;現象二因スルモノナルベ，從ッテ既二迅 ベルル型ノアプタスマ細鸠」ノ出現も亦之等卜其 ノ规マーニスルモノト解ンナ可ンラン.

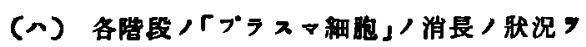
總括的ニ国示スレベ第3 圆 $/$ 如シ.

郎チ第 4，第 5 病日 =於テ「プラスマ細胞」采が

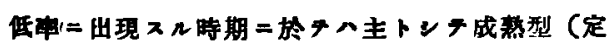
型) ニンテ他ノ隌級ノモノへ出現せザルカ，或八

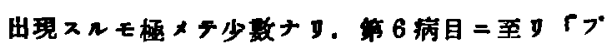
フスマ緗胞」系が㙁加フ開始スルヤ、「前ブラスマ

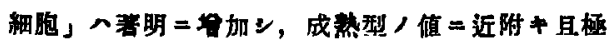

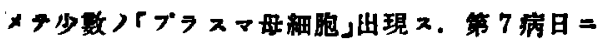

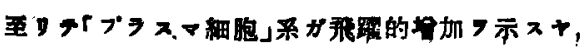

「前ブラスマ䎩胞」へ更ニ多数二出現ントブラスマ

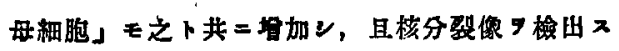
ル 9 常ト七y.

第3圆「プラスマ細胞」各型ノ洞長

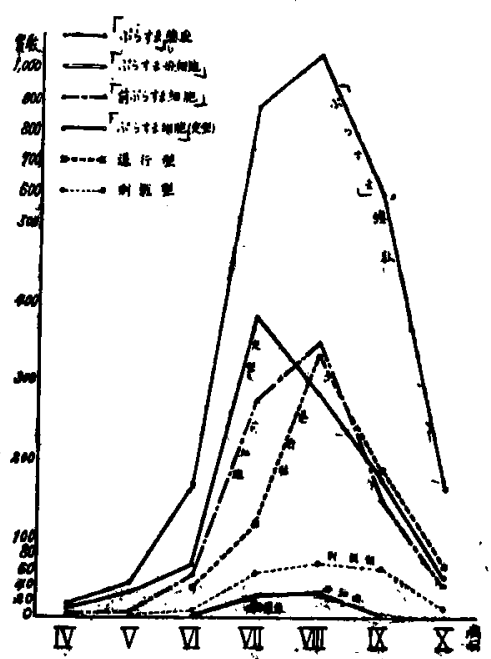

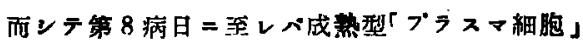
八既 =消退 9開始スルモ「前ブラスマ湅胞」及゙ビ

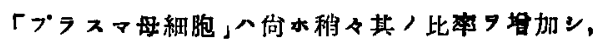
第 9 病日 $=$ 至リ「プタス、細胞」系调落 細胞八殆ド消失ン，「前プラスマ細胞」八倘ホ多

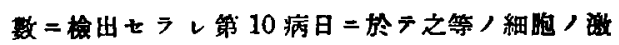

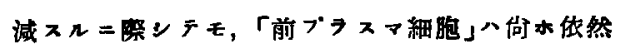

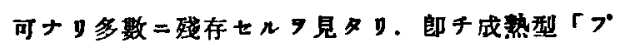
フスマ細胞」八最初ヨy大多數す占メ「ブタスマ 細垉」系增加期 =八常二首位 八他型ニ先ンジ減少ス.

办「前 ブラスマ細胞」へ初期 ニ於テへ成热型 =比

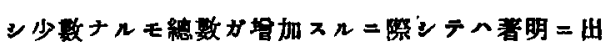

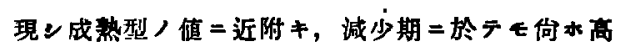

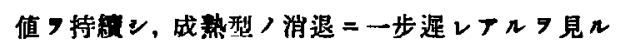

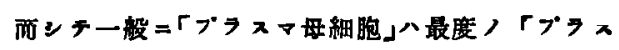
マ細胞渦多症」、現出七几時ニノミ检出七ラル。 刺戟型八初期 (第 4一第 6 病日)甚名低率 $=$ 出現

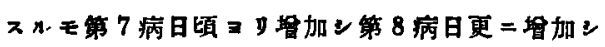

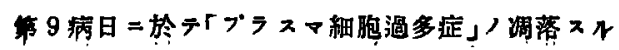
43 


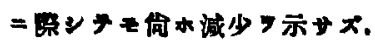
亦「ブフスマ細胞」ノ退行型八初期检出をフレザ

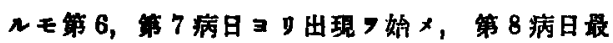

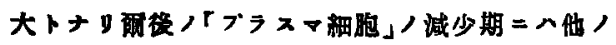

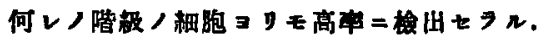

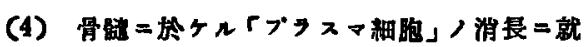

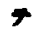

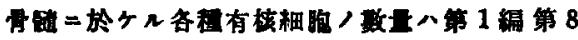

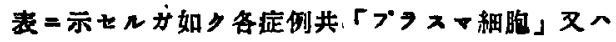

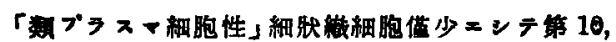
8,7 例/如り末梢血液中=夫ょ $11 \%, 13.5 \%$ 及ヒ

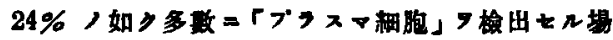
合卜䠰モ情肉ニー3\%以下

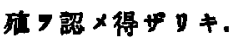

\section{第 4 主 總括端二考按}

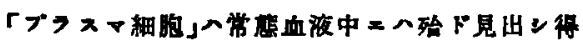

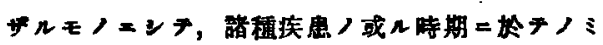

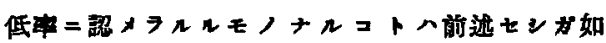
ン. 而ンテ稀ニ「ブラスマ細胞過多症」フ㭟起スル

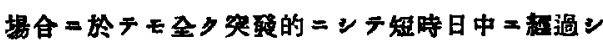
了ルモノナル事へ周知ノ事宾ナり.

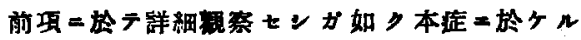

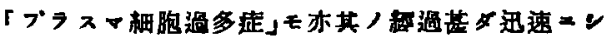

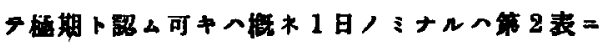

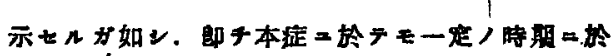

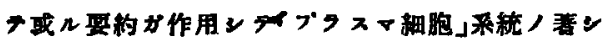

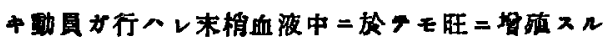

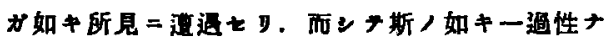

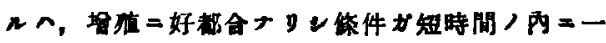

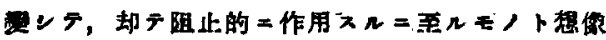

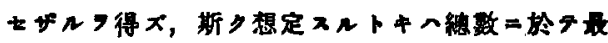

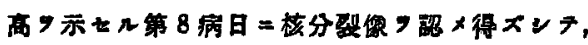

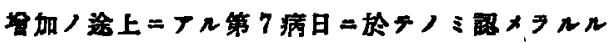
事宽モ首肯七ラレ，又成整刑「プラスマ細胞」ト

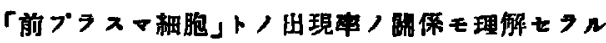
ヘン。即チ「ブラスマ細胞っガ $2 \%$ 以下ノ低值二出

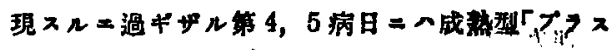
マ細胞」ガ主ナルモ「ブフスロ細胞過多症」ノ前牛

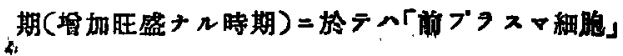

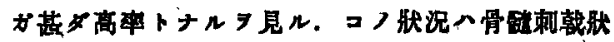

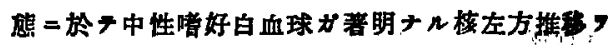

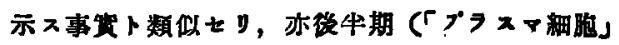

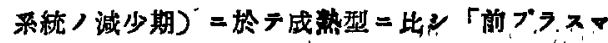

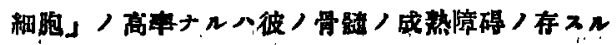

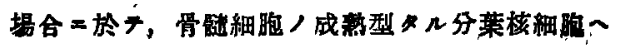

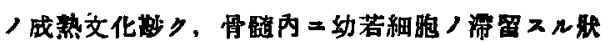
识ト数似七り．亦「ブラスマ細胞」ノ退行型八前伴

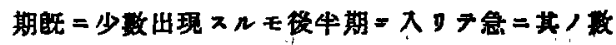

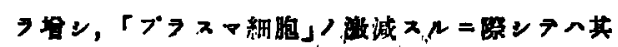

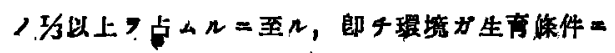

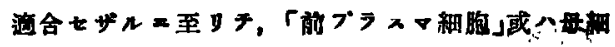

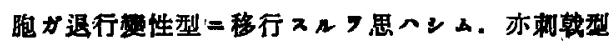
ノ䈍店モ同橉=シテ本細胞 暴型的酸青

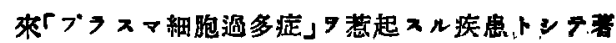
明ナルモノ=風疮及ビ血清病厂】.

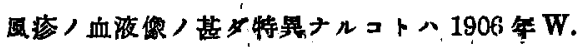

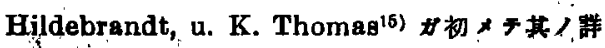

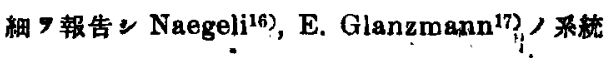

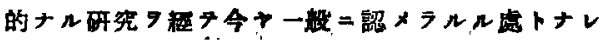
y.

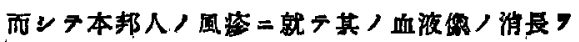

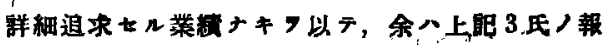

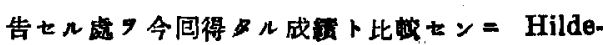

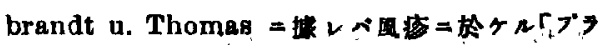

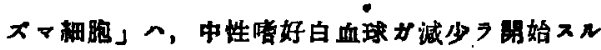

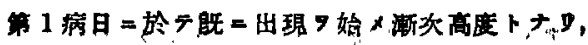
第 4 病日：於テ柾倠 7 示スモ，中性啳好白血球へ

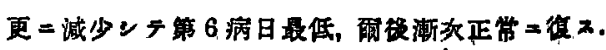

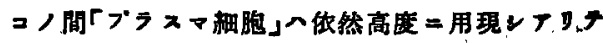

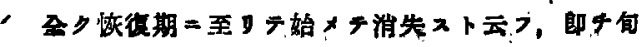

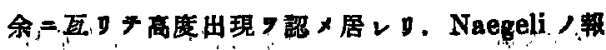

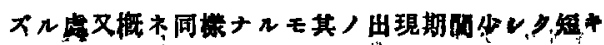




\section{高山論文附國}

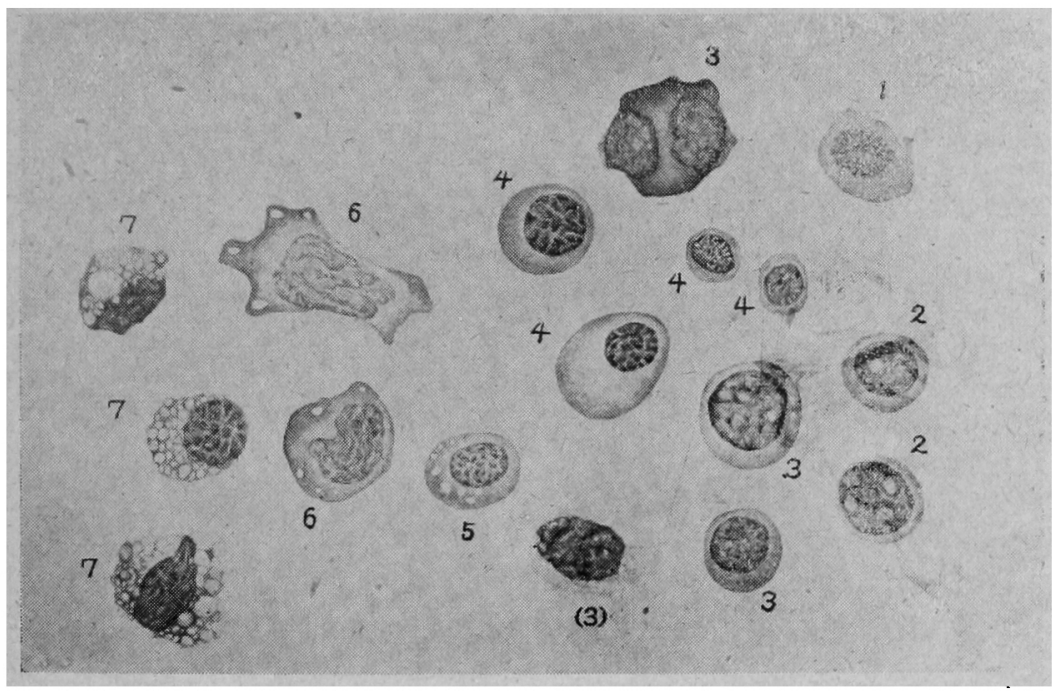

附 圖 說 明

「プラスマ細胞過㐱症」ノ末梢血液中二見出ンタル誏系統細胞ノ諸相の示ス。

1. 核彷裂像

2. 「ブラスマ母細胞」 ‘

3.「前ブラスマ細胞」其ノ内 1 笛へ2核性ナリ

（3）「前ブラメマ細胞」ノ退行教性

4. 「プラスマ細胞」

5.「パラプラスマ細胞」(チニルク氏刺戟型)

6. 單純黄性型

7. 粘液焏性型 
才如ン，然と共 Glanzmann =譃レペ，第 1 病日

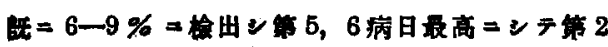
遇二入几モ消失たズ，第 14 病日 $13 \% ，$ 第 20 病日

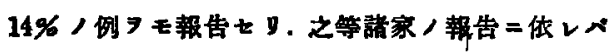

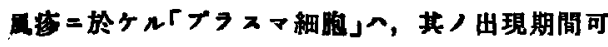

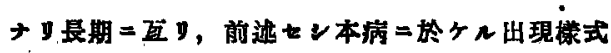
トの可ナり/倳虫フルフ知ル.

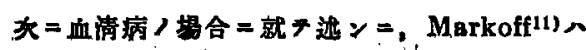

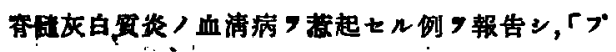

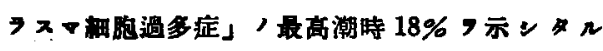

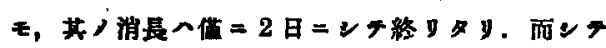

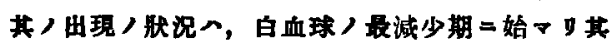

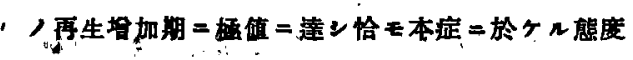

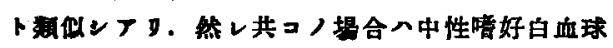

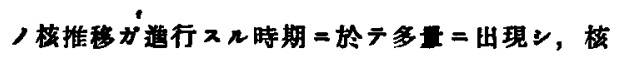

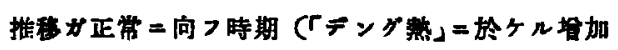

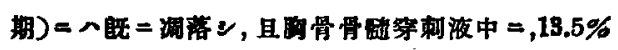

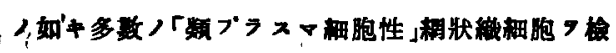

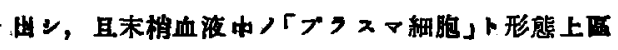

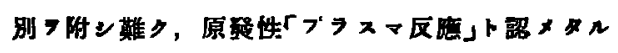

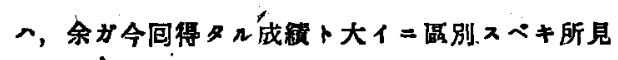
+y.

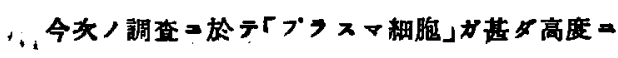

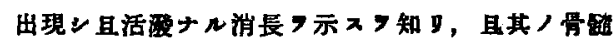

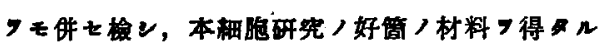
フ以テ其/發生二就ま以下若干考察をントス.

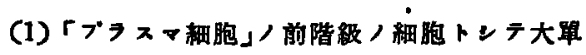

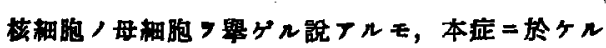

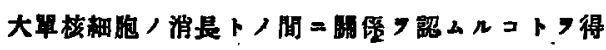
$\neq 0 \neq$.

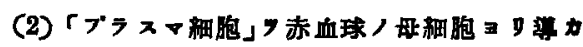

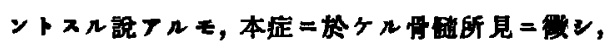
そフ立證スルコトラ得サンンサり。

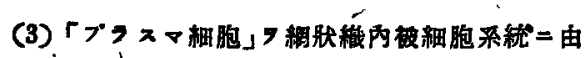

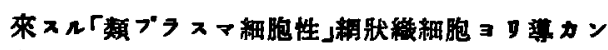

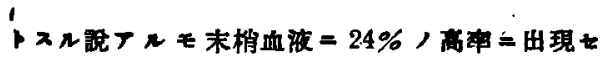

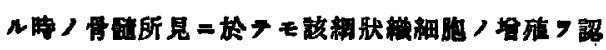

$x+9 \neq$.

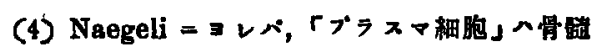

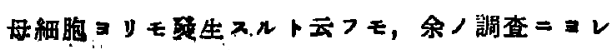

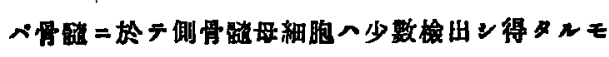

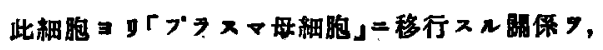
コノギームザ法標本二就テハ检明スコトフ得ザ

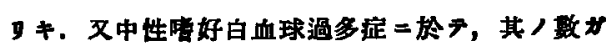

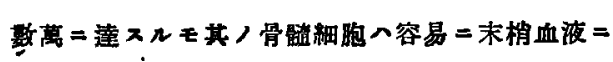

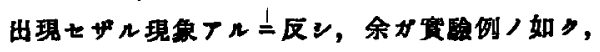

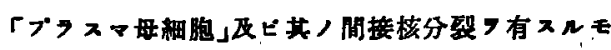

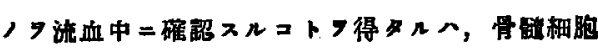

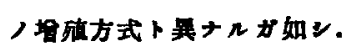

(5) 現今最玉有カナル「プラスマ緗胞」本熊

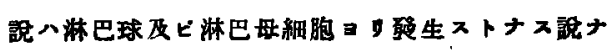
3.

本症二於とル「プフスマ細胞」ノ一過性境加へ恰

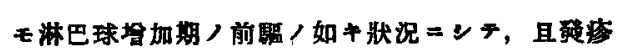

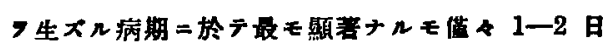

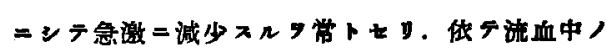

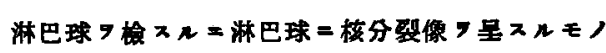

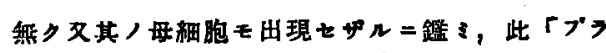

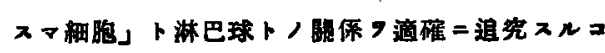
$ト$ 得サ $\boldsymbol{9} \neq$.

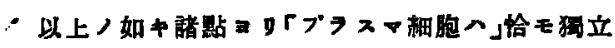

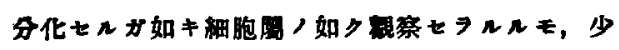

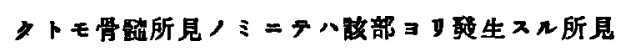

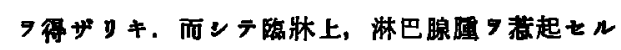
例二特ニ著明ナルラ以テ之等，践器卜何等力八交 涉フルカノ如ク思考スルナy。

\section{第5 結 論}

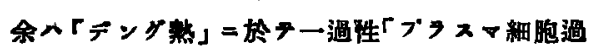

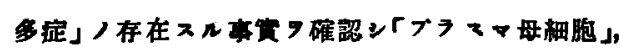
「前プラスマ細胞」,「プラスマ細胞」, 刺戟型, 退

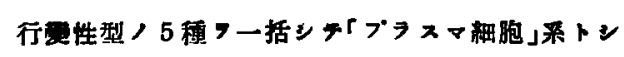

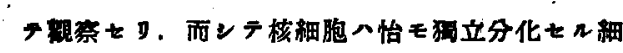

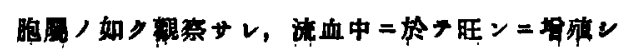


ツッフルフ憙メンリ。

「ブラスマ細胞」ノ一過性ノ過多定へ全例二於テ 38.25-3.5\% = 检出七フル。就中淋巴腺堙腲 7 件

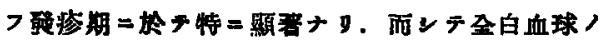

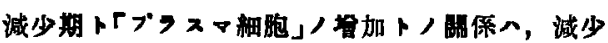

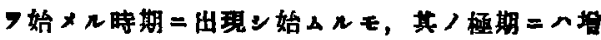
加せザルラ常トス. 然レ共其/白血球ガ再ビ㙁加

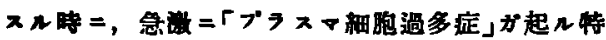

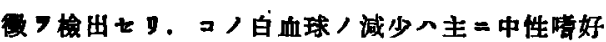

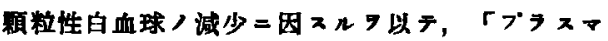

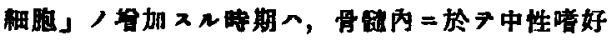

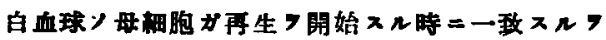

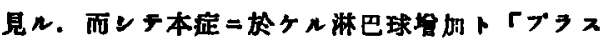

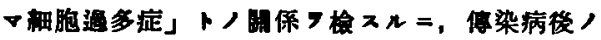
淋巴球過多症ガ起几前巴期 =一致ン，其/淋巴球

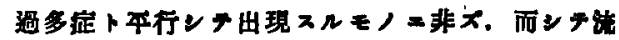

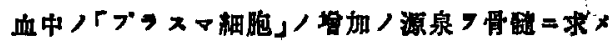
ント校ン，之マ細检センモ，何等ノ㭪捉ス可中所 見得ザりキ。

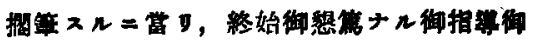

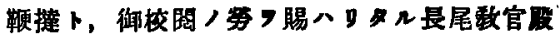

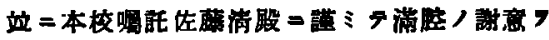

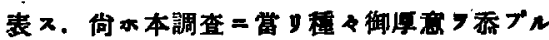

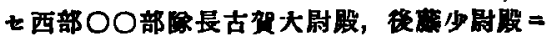
謝謝 ス。

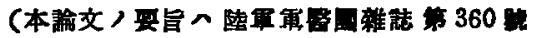

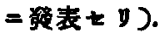

\section{呈 要 文}

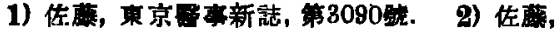

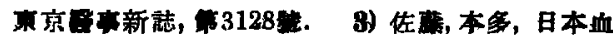

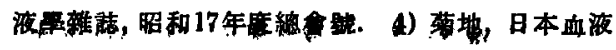

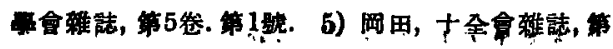

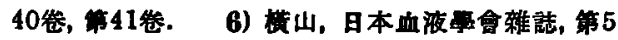

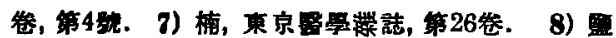
見, 日本病理學㝓雜誌, 第7甞. 9) Marschalko, Zbl. f. pllg. Path. 1896, 5.851. 10) Türh, Wien. Klin. Wschr. 1907, \$o. 6. 11) Markoff, Dent- sch. Arch. f. Klin. Med. Bd. 180, $1937 . \quad$ 12) Sehwaer, Münch. Med. Wechr. 1918. Schick, Ergeb, d. inn. Med. $\mu$. Kinderbeilk. 5, Bł. 1910. 14) Keller, Neu. Dentsch. Klinik Bd. 9, 1932 . 15) Eildebrandt u. Thomas, Z. t. Klin. Med. Bd. 59, $1906 . \quad$ 16) Naegeli, Spez. Path. u, Therapie inn. Kht. Bd. 8, 1920. 17) Glanzmonn, Schweiz. Med. Wrachr. 1929.

(昭和 18 年5月 1 日受稿)

Student der Hygienischen Abteilung der Wehrmedizinischen Inneren Klinik der Militä̈ärratlichen Aleademie.

(Vorstand : Generaloberarat $H$. Osuzu)

Studien iiber Dengue.

H. Lher die bei der genanntey Krankheit hosonders bequtenswarte tempoläre Plasmazyłose.

Von

Obprsfabsgrqt Yoshițak Toqkqyama,

Dingegangen am 1. Mai 1945. 
In der vorhergehenden Mitteilung wurde festgestellt, dsas bei Dengue unmittelbar nach der Entfieberung eine sehr hochgradige Plasmazytose tempolär auftritt, ein Symptom, welohes differenzialdiagnostisoh von wichtiger Bedeutung sein muss. Dabei vermebrt sich die Réble der Plasmazellen in so lebendiger Weise, dass oie als eine selbstāndig differensierte Zelleriárít gelben' kann. Der Verf. bát sie daher in 1) Flathbiblasten, 2) Praeplanmazellen, 3 ) Plasmazellen, 4) Tūrksche Reizform und 5 ) Degenerationsform, welche letztere wiederum in i) einfache und ii ) mucöse Degenerationsform, und jedes ferner in grosse $(20-24)$, mittleré $(16-18)$ und kleine Frorm $(10-13)$ eingeteilt, um die quantitativen Schwankungen der einzelnen Klasse eingehend zu beobachten.

Die tempoläre Pílasmazytose liess sich in $38,25-3,5 \%$ der gesanten Fälle feststellen. Sie tritt im Stadium des mit Schwellung der Lymphdrüse einhergehenden Exanthems in besonders erheblichem Masse auf. Die Vermehrung der Plasmazellen beginnt gerade im Anfang des Abnahmestadiums der gesamten Leukozyten, im Maximalstadium dieser Abnahme jedoch erfolgt gewöhnlich keine Vermebrung der Plasmazellen. Dabei wurde die charakteristische Erscheinung festgestellt, dass in dem Stadium, wo die Leukozyten wieder zuzunehmen beginnen, rasch die tempoläre Plasmasytose stattfindet. Aus der Tatsache, dass die Abnahme der Leukozyten in der Hauptsache auf der Abnahme neutrophilér granulierter Leukozyten beruht, geht hervor, dass der Zeitabschnitt der Zunahme der Plasmazellen mit dem übereinstimmt, wo die Mutterzellen der neutrophilen Leukozyten im Knochenmark sich zu regenerieren beginnen. Die Beziehung zwischen der $\dot{V}$ ermehrung der Lymphozyten und der Plasmazytose besteht darin, dass die letztere nach der Infektion im Vérlauf des' Ṕrodromalstadiums' der Lymphozytose in die Erscheinung tritt, nicht aber der Lymphozytose parallel geschieht. Der V̀erf. hat darum einmal vorgenommen, die Quelle für dié im kreisenden Blut auftretende Vermehrung der Plasmazellen in dem Knochenmark nachzuweisen, ohne jedoch irgendeinen greifbaren Befund erheben zu kōnnen.

(Autoreferat) 